University of Texas Rio Grande Valley

ScholarWorks @ UTRGV

Bilingual and Literacy Studies Faculty

Publications and Presentations

College of Education and P-16 Integration

$9-28-2018$

\title{
Strengthening the Reader Self-Efficacies of Reluctant and Struggling Readers Through Literature Circles
}

Elena M. Venegas

The University of Texas Rio Grande Valley, elena.venegas@utrgv.edu

Follow this and additional works at: https://scholarworks.utrgv.edu/bls_fac

Part of the Modern Languages Commons, and the Other Languages, Societies, and Cultures

Commons

\section{Recommended Citation}

Venegas, Elena M. "Strengthening the Reader Self-Efficacies of Reluctant and Struggling Readers Through Literature Circles." Reading \& Writing Quarterly, vol. 34, no. 5, Routledge, Sept. 2018, pp. 419-35. Taylor and Francis+NEJM, doi:10.1080/10573569.2018.1483788.

This Article is brought to you for free and open access by the College of Education and P-16 Integration at ScholarWorks @ UTRGV. It has been accepted for inclusion in Bilingual and Literacy Studies Faculty Publications and Presentations by an authorized administrator of ScholarWorks @ UTRGV. For more information, please contact justin.white@utrgv.edu,william.flores01@utrgv.edu. 


\title{
Strengthening the reader self-efficacies of reluctant and struggling readers through literature circles
}

\author{
Abstract \\ Although a subskills approach to reading instruction is merited in improving the reading \\ skills of struggling readers, struggling readers also benefit from balanced literacy instruction. \\ Overemphasis on reading subskills arguably minimizes students' enjoyment of and motivation to \\ read and may inevitably result in the formation of reluctant or struggling readers. In turn, the \\ self-efficacies of reluctant or struggling readers may be diminished. Framed by social cognitive \\ theory, the author designed an embedded multiple case study to explore the potential influence of \\ literature circles, a balanced literacy instructional strategy, on the reader self-efficacies of \\ reluctant and struggling readers in Grades 4-6. In terms of reader self-efficacy, reluctant and \\ struggling readers appeared to benefit more from participating in literature circles than their \\ classmates (i.e. students with initially higher reader self-efficacies). This study is significant in \\ providing support for a more balanced approach to reading instruction, particularly for reluctant \\ and struggling readers.
}


Strengthening the reader self-efficacies of reluctant and struggling readers through literature circles

\section{Introduction}

Struggling readers are more likely to receive teacher-centered, subskills-focused reading instruction than more proficient readers (Allington, 1983). Instruction in reading subskills is merited and supported by research (Scammaca, Roberts, Vaughn \& Stuebing, 2015; Wanzek, Wexler, Vaughn, \& Ciullo, 2010) yet too often is the predominant form of reading instruction received by struggling readers (Allington, 1983). Struggling readers with low self-efficacy often doubt their reading skills can be improved (Cho et al., 2015.) Thus, struggling readers require a more balanced approach to literacy instruction to develop, hone, and successfully apply their reading skills within the context of authentic literacy. In this paper, the author argues that literature circles — a balanced literacy instructional strategy — can potentially strengthen the reader self-efficacies of reluctant and struggling readers.

A meta-analysis conducted by Scammacca et al. (2015) revealed struggling readers in Grades 4-12 receive primarily skills-based reading intervention, which can improve reading comprehension, fluency, and vocabulary. Thus, there is evidentiary support that targeted skillsbased intervention is beneficial for struggling readers in Grades 4-12 (Scammacca et al., 2015). A similar synthesis of reading interventions for Grades 4-5 students with reading difficulties and/or disabilities found researcher-developed interventions were particularly successful in helping students to improve their reading comprehension (Wanzek et al., 2010). Whereas reading subskills are foundational to literacy success, they cannot be the sole focus of reading instruction, particularly as students enter Grade 4. Kim et al. (2016) caution, "Improvements in reading subskills, however, are not sufficient for deep comprehension” (p. 358). Moreover, reading instruction begins to shift in Grades 4-6 from developing reading subskills to applying those skills to increasingly difficult texts (Kent, Wanzek, \& Al Otaiba, 2017). Yet opportunities to 
Strengthening the reader self-efficacies of reluctant and struggling readers through literature circles

partake in authentic literacy experiences may be absent when a subskills approach to reading instruction is overemphasized.

"Despite the fact that balanced reading instruction is supported by the International [Literacy] Association, some schools have shifted toward direct instruction characterized by teacher-centered reading approaches" (Thames et al., 2008, p. 89). This is particularly true for struggling students whom Allington (1983) found were provided more skills-focused reading instruction whereas their peers received comprehension-focused instruction and read authentic texts. Allington (1983) argued, "Good and poor readers differ in their reading ability as much because of differences in instruction" (p. 548). Like their peers, struggling readers benefit from reading instruction that encourages critical thinking as well as engaging in listening, reading, writing, and dialoguing (Thames et al., 2008). Recent research conducted by Kim et al. (2016) studied the effect of Strategic Adolescent Reading Intervention (STARI), a supplemental reading program melding skills-based instruction with text-based discussion, on struggling readers in Grades 6-8. Students who received the STARI intervention outperformed the control group in terms of word recognition, morphological awareness, and reading comprehension (Kim et al., 2016). Improving reading achievement as well as fostering students' enjoyment of and motivation to read warrants a more balanced approach to reading instruction (i.e. mediating a reading subskills approach with authentic opportunities to engage in reading, writing, and speaking).

Yet improving the reading achievement of reluctant and struggling readers necessitates improving their reader self-efficacies. Self-efficacy refers to an individual's belief that he or she can succeed at a given task (Bandura, 1997). Oftentimes, struggling readers have low reader selfefficacies (Ferrara, 2005). Thus, struggling readers must come to believe they can read 
Strengthening the reader self-efficacies of reluctant and struggling readers through literature circles

successfully by applying learned skills and strategies (McCabe \& Margolis, 2001). Readers with low self-efficacies are unlikely to transfer their learning from the context in which they acquired their knowledge and skills to a different one (McCabe, 2003). Thus, self-efficacy can influence a struggling reader's application of learned reading skills and strategies. Upon receiving reading intervention, Cho et al. (2015) found the reading outcomes of students with low reading comprehension yet higher self-efficacies were more likely to improve than students with lower self-efficacies.

For this study, the author distinguishes between reluctant readers and struggling readers. A reluctant reader is capable of reading (i.e. he or she has the skills to read) yet does not unless necessary for work or daily life (Chambers, 1969). A struggling reader often reads below grade level (Hoyte, 2006). The terms reluctant reader and struggling reader are often used synonymously. As Beers (1996) explains, a reluctant reader (i.e. person who does not enjoy reading) may evolve into a struggling reader due to a lack of reading practice. A lack of balanced literacy instruction can be detrimental to all students, but particularly to reluctant and struggling readers. Thus, the purpose of this embedded multiple case study was to explore the potential influence of participating in literature circles on the reader self-efficacies of reluctant and struggling readers.

\section{Review of Literature \& Theoretical Framework}

Literature circles fall within the realm of balanced literacy instruction. Carrison \& ErnstSlavit (2005) explain, "The literature circle model, as a part of a balanced literacy program provides abundant opportunities for dynamic interaction among readers and text" (p. 110). A literature circle is a "small, peer-led discussion group whose members have chosen to read the same story, poem, article, or book" (Daniels, 2002, p.2). Ultimately, the goal of literacy 
Strengthening the reader self-efficacies of reluctant and struggling readers through literature circles

instruction is to equip students to read authentic literature (Cooper, Robinson, Slansky, \& Kiger, 2015). Authentic literature refers to trade books, or narrative and expository texts in their original forms (Cooper et al., 2015), and contrasts basal readers created specifically to teach reading subskills. As a literature circle participant, each student reads authentic literature while honing his or her literacy skills. In preparation for literature circles, a student may engage in one or more of the following processes: (1) making predictions, (2) identifying important information, (3) making inferences, (4) monitoring comprehension, (5) seeking clarification, (6) asking and answering questions, (7) visualizing, and (8) summarizing (Whittaker, 2012). Each of these processes is a research-based strategy for constructing meaning (Cooper et al., 2015).

Research attests to the potential benefits of literature circles. For example, participating in a literature circle promotes higher-order thinking through student-centered instruction (Cameron, Murray, Hull, \& Cameron, 2012). Text-based discussions, such as those at the heart of literature circles, help students to develop reading strategies, improve prosody, increase students' stamina and perseverance, and develop critical literacy skills (Pearson, 2010). Literature circle participation improves reading comprehension (Clarke \& Holwadel, 2007) and relatedly, benefits students with low reading comprehension (Avci \& Yuksel, 2011). Literature circles increase students' motivation to read (Stein \& Beed, 2004) and improve reluctant readers' enjoyment of reading (Cameron et al., 2012). Therefore, literature circles are promising for reluctant and struggling readers.

Some commonalities between the present study and a study conducted by Hall (2012) exist, including a focus on struggling readers, the instrument used to measure reader selfefficacy, and the utilization of text-based discussions. Hall (2012) utilized the Reader SelfPerception Scale (RSPS) (Henk \& Melnick, 1995) as one data source in her study of struggling 
Strengthening the reader self-efficacies of reluctant and struggling readers through literature circles

readers' interactions in text-based discussion groups. Hall (2012) found struggling readers were initially reserved in their text-based discussion groups yet began to contribute more over the course of their group meetings. The author's study, however, differs from Hall (2012) in its focus on reader self-efficacy and the inclusion of reluctant readers as participants. Thus, this study is unique in relation to research on both self-efficacy and literature circles.

The author approached this study through the lens of social cognitive theory, fathered by Albert Bandura. Bandura (2001) postulated that humans are cognitive agents influenced by their own thoughts and beliefs, including self-efficacy. This study-focused on the influence of participating in literature circles on the reader self-efficacies of reluctant and struggling readers in an intermediate grades classroom — was framed by social cognitive theory.

Self-efficacy is defined as confidence in one's "ability to organize and execute a given course of action to solve a problem or accomplish a task" (Bandura, 1997, p. 3). Self-efficacy is task-specific (McCabe, 2003). Thus, a student may have higher self-efficacy in one content area (e.g. mathematics) but lower self-efficacy in another (e.g. English language arts and reading). Four sources of information compose self-efficacy: (1) mastery experience (2) vicarious experience (3) feedback and (4) physiological states (Pajares, 2003). One’s self-efficacy influences task engagement, amount of effort put forth towards accomplishing the task, and persistence in the face of difficulty (Bandura \& Schunk, 1981). Therefore, literacy educators must understand the role of self-efficacy in learning.

An individual's cognitive ability as well as self-efficacy influence his or her literacy development (Corkett, Hatt \& Benevides, 2011). Furthermore, self-efficacy as a motivational factor can likewise influence literacy development (Schunk \& Zimmerman, 2007). Readers with low self-efficacies may avoid or withdraw from tasks perceived as too difficult (Guthrie et al., 
Strengthening the reader self-efficacies of reluctant and struggling readers through literature circles

2007; Zimmerman, 2000). Consequently, readers with low self-efficacies may miss opportunities

to improve their reading comprehension (Solheim, 2011). Pajares (2003) cautions unwarranted

low self-efficacy, rather than ability, can diminish a student's academic achievement.

Furthermore, recent research underscores the connection between self-efficacy and literacy development/achievement (Corkett et al., 2011; Solheim, 2011; Smith et al., 2012).

Research suggests self-efficacy influences reading enjoyment, reading comprehension, and literacy-related achievement. Smith et al. (2012) found a correlation between reading selfefficacy and reading enjoyment. The researchers found Grade 4 and Grade 8 students with higher reading self-efficacies viewed reading as more enjoyable than their peers with lower reading self-efficacies (Smith et al., 2012). Solheim (2011) found a correlation between reading selfefficacy and reading comprehension. Grade 5 students with high reading self-efficacies performed well on both multiple choice and created-response reading comprehension questions (Solheim, 2011). Readers with low self-efficacies, however, performed better on createdresponse than multiple-choice questions (Solheim, 2011). Solheim's (2011) research underscores the influence of a student's self-efficacy on measures of reading achievement. In an era of highstakes testing, such findings denote the importance of improving students' self-efficacies to improve their reading comprehension and aptitude for multiple-choice standardized tests. Corkett et al. (2011) also found a connection between students' literacy (i.e. reading and writing) achievement and their self-efficacies. In their study, teachers' perceptions of their students' reading self-efficacies correlated with their students' reading and writing abilities (Corkett et al., 2011). Literature circles - an engaging, student-centered instructional strategy utilizing authentic literature_can foster reading enjoyment, comprehension, and achievement. 
Strengthening the reader self-efficacies of reluctant and struggling readers through literature circles

There is a need to study the reader self-efficacies of Grades 4-6 students on two fronts. First, previous research suggests Grades 4-6 students often fail to appraise accurately their reading self-efficacies (Corkett et al., 2011; Linnenbrink \& Pintrich, 2003; Pajares, 2003; Smith, Smith, Gilmore, \& Jameson, 2012). This is an issue of calibration or the notion that one's perceived self-efficacy is an accurate reflection of his or her actual performance (Linnenbrink \& Pintrich, 2003). The ability to calibrate accurately one's self-efficacy with one's ability improves with age (Shell, Colvin, \& Bruning, 1995). However, low self-efficacy can supersede skill (Bandura, 1997), which is potentially dangerous for readers in Grades 4-6. Since reading motivation is known to decline in adolescent years (Unrau \& Schlackman, 2006), educators must intentionally build the reader self-efficacies of Grades 4-6 students who are transitioning into adolescence. Second, the onus is on Grades 4-6 teachers to cultivate their students' reader selfefficacies. Teachers in a study conducted by Corkett et al. (2011) were unaware of the role literacy-related self-efficacy played in their students' achievement. However, teachers need to be intentional in strengthening their students' reading self-efficacies. Schunk \& Zimmerman (2007) recommend teachers build students' self-efficacies through encouraging feedback as well as opportunities to gain mastery experiences. For example, teachers can utilize cooperative learning opportunities to build a student's self-efficacy through vicarious experience (Schunk \& Zimmerman, 2007). Cooperative learning enhances vicarious experience as a student will likely identify with at least one model in the group (Schunk, 1987). The focus on self-efficacy within the context of cooperative learning via literature circles led the author to frame this study from the perspective of social cognitive theory.

\section{Methodology}

\section{Purpose of the Study}


Strengthening the reader self-efficacies of reluctant and struggling readers through literature circles

The purpose of this embedded multiple case study was to explore the influence of literature circle participation on the reader self-efficacies of reluctant and struggling readers in a Grades 4-6 classroom. This study was primarily qualitative with quantitative data collection embedded to enhance its robustness. An embedded case study integrates quantitative data into a primarily qualitative study (Yin, 2014). A common justification for utilizing both qualitative and quantitative data is to facilitate triangulation, specifically in "seeking corroboration between quantitative and qualitative data" (Bryman, 2006, p. 105). The use of multiple cases in this study further illustrated the issue (Creswell, 2013) of the reader self-efficacies of reluctant and struggling readers. Herriott \& Firestone (1983) assert that multiple case studies are more robust because data from several cases inform generalizations made from collected data. Quantitative data—collected via the RSPS (Henk \& Melnick, 1995) — served to supplement the findings from qualitative data. The design of an embedded multiple case study was selected to best suit the research question.

\section{Research Question}

The research question at the center of this study asked, how does participating in a literature circle influence the reader self-efficacies of reluctant and struggling readers? Prior to collecting data, the author predicted engaging in literature-based conversations would positively influence, or strengthen, the reader self-efficacies of the reluctant and struggling readers who participated in this study.

\section{Site of this Study}

The site of this study was a Grades 4-6 classroom within a central Texas public school. The author elected to study reluctant and struggling readers in these grades because negative attitudes towards reading often begin in these formative years (Brinda, 2011). Data collection 
Strengthening the reader self-efficacies of reluctant and struggling readers through literature circles

occurred in the classroom of Mrs. Ian (pseudonym). The school at which this study was

conducted was selected because it was fairly representative of public schools within the region.

\section{Sampling Procedure}

All 20 students in Mrs. Ian's classroom participated in literature circles. However, only 17 students participated in this study. The parents of one student did not consent to her participation in this research study; the data of another student was incomplete and could not be utilized. One student receiving special education services also did not participate. Although 17 students participated in this study, only seven were identified as cases for further study. Criterion-based purposeful sampling was employed to identify each case. Palinkas et al. (2013) describe criterion-based purposeful sampling as "identify[ing] and select[ing] all cases that meet some predetermined criterion of importance" (p. 535). The criterion for being identified as a case in this study was to have a comparatively low reader self-efficacy score as self-reported via the Reader Self-Perception Scale (RSPS) (Henk \& Melnick, 1995) as well as be identified as a reluctant or struggling reader by Mrs. Ian.

In September of 2016, the author supervised Mrs. Ian's students as they independently completed the RSPS (Henk \& Melnick, 1995) pre-test. The author then scored the pre-tests and rank-ordered the students from the highest RSPS pre-test score (i.e. highest self-reported reader self-efficacy) to the lowest RSPS pre-test score (i.e. lowest self-reported reader self-efficacy). Subsequently, the author identified the seven students with the lowest pre-test scores, or lowest self-reported reader self-efficacies, as potential cases. The author then asked Mrs. Ian to identify each potential case as a reluctant reader, struggling reader, or neither (thereby excluding him or her as a case.) Mrs. Ian's professional judgment served to identify potential cases because the 2016-2017 school year was the second or third year that Mrs. Ian taught many of her students 
Strengthening the reader self-efficacies of reluctant and struggling readers through literature circles

(i.e. those in Grades 5 and 6, respectively). A meta-analysis of 75 studies found "the correlation between teachers' judgements of students' academic achievement...is positive and fairly high (.63)” (Südkamp, Kaiser, Möller, 2012, p. 755.) Quantitative data, via the RSPS pre- and posttests, was collected from each study participant. However, qualitative data was collected only for the seven students who met the aforementioned criteria and thereby served as cases in this study.

\section{Cases}

The cases in this study were representative of the larger school population-six out of the seven were students of color. Two cases represented each grade level, with the exception of Grade 5 from which three cases participated. Mrs. Ian identified three of the cases as reluctant readers, two as struggling readers, and two as both reluctant and struggling readers. Table 1 shows the demographic data of each case.

\section{Literature circles in Mrs. Ian's classroom'}

As there is not a uniform manner by which to implement literature circles, it is important to contextualize those within Mrs. Ian's classroom. Literature circles are essentially book clubs structured for school settings. Apart from a few defining characteristics (i.e. small groups discussing the same text), educators have a great amount of freedom in how they structure literature circles. The literature circles observed for this study occurred over an eight-week period from November 2016 to January 2017 (excluding holiday breaks). The students voted to read the same novel: Rules (2008) authored by Cynthia Lord. The seven cases (i.e. students identified as reluctant and struggling readers) and ten other study participants (i.e. students with higher reader self-efficacies) intermingled within literature circles. Both quantitative and qualitative data were collected for this embedded multiple case study prior to, during, and following the eight-week literature circle cycle. 
Strengthening the reader self-efficacies of reluctant and struggling readers through literature circles

\section{Data Collection}

Data from a variety of sources was collected to allow for triangulation, including: (1) RSPS pre- and post-test scores (2) individual interviews with cases and classroom teacher (3) direct observations (4) documentation (i.e. literature circle role sheets) and (5) a focus group. The use of multiple data sources allows facilitates triangulation to corroborate evidence (Lincoln \& Guba, 1985) and provides validity to research findings (Creswell, 2013).

The Reader Self-Perception Scale. The author utilized the RSPS (Henk \& Melnick, 1995) because it is an instrument created specifically to measure the reader self-efficacies of Grades 4-6 students (Henk \& Melnick, 1992). Four scales comprise the RSPS: (1) Progress-a measure of the student's perceived reading performance in comparison with his or her past performance, (2) Observational Comparison - a student's perceived reading performance relative to his or her peers, (3) Social Feedback, in which the student reflects on input from his or her teachers, classmates, and family, and (4) Physiological States - a measure of the internal feelings experienced by the student while reading (Henk \& Melnick, 1995). Each subscale of the RSPS (Henk \& Melnick, 1995) corresponds to one of four factors composing self-efficacy. The statement "I think I am a good reader" is included on the RSPS as a measure of general reader self-efficacy. Over 2,100 Grades 4-6 students across a variety of school contexts (i.e. rural, suburban, and urban) served in norming the RSPS, which is both reliable ( $\alpha=.81$ to .84) and valid (Henk \& Melnick, 1995). Results from pre-test and post-test administrations of the RSPS comprised the quantitative strand of data collected for this study, which allowed the author to gauge, quantitatively, the influence of literature circles upon participants' reader self-efficacies. As previously mentioned, a self-administration of the RSPS was taken by all study participants as a pre-test in September of 2016 prior to the observed literature circle cycle. The RSPS was 
Strengthening the reader self-efficacies of reluctant and struggling readers through literature circles

again self-administered by all study participants as a post-test in February of 2017 following the conclusion of the observed literature circle cycle. Additional, qualitative data was collected on the seven cases who merited further study.

Interviews. The author conducted an individual interview with each case in October of 2016, prior to his or her participation in the observed literature circles. In February of 2017, after the conclusion of the literature circle cycle, the author individually interviewed each case once again. All interviews were audiotaped to ensure all responses were accurately recorded, as suggested by Yin (2014). The author likewise interviewed Mrs. Ian following the eight-week literature circle cycle, as she was instrumental in helping the researcher to identify the seven cases for further study. During this interview, Mrs. Ian was asked to reflect on the eight-week literature circle cycle as well as the cases as readers prior to and following participating in literature circles.

Direct observations. Observation involves coupling the observer's senses with an instrument to note a phenomenon within the field (Angrosino, 2007). Each week, from November 2016 to January 2017, the author visited each literature circle as it met to discuss Rules (2008). During these observations, the author assumed the role of participant observer to allow for full interaction with the cases (Creswell, 2013). A checklist developed by Day, Spiegel, McLellan, \& Brown (2002) coupled with an open-ended observational protocol developed by the author were used to note the interactions of the cases with others.

Documentation. For each literature circle meeting, Mrs. Ian assigned each student a role and expected him or her to read the text through the lens of the assigned role. The respective role assigned to each participant changed from week to week. The roles were as follows: (1) Artful Artist - illustrates characters and/or pivotal scenes in the text (2) Connector-makes text-to-self, 
Strengthening the reader self-efficacies of reluctant and struggling readers through literature circles

text-to-text, and text-to-world connections (3) Discussion Director-guides discussion through questioning (4) Literacy Luminary_identifies memorable and/or important passages in the text (5) Summarizer — summarizes the chapter(s) read and (6) Word Wizard—identifies interesting and/or puzzling words encountered in the text. For each literature circle meeting, each participant prepared a role sheet. The author analyzed only those role sheets prepared by the seven cases, which served as documentation in this study.

Focus group. Following the eight-week literature circle cycle, the author conducted a focus group with six of the seven cases. The purpose of the focus group was to gain further insight into the cases' experiences in literature circles as well as any influence literature circles had on them as readers.

\section{Data Analysis}

Qualitative data analysis occurred via the data analysis spiral (Creswell, 2013). After organizing the data using NVivo 11 software, the author read the qualitative data in its entirety prior to memoing, described by Creswell (2013) as taking note of "short phrases, ideas, or key concepts that occur to the reader" (p. 183). After memoing, the author categorized the data before coding it into themes, or common ideas resulting from the aggregation of several codes, as recommended by Creswell (2013).

To conduct within-case analysis, the author engaged in pattern matching, described by Yin (2014) as comparing "an empirically based pattern" (p. 143) that evolves from the data to a pattern predicted prior to collecting said data. As previously stated, the author predicted participating in a literature circle would positively influence the reader self-efficacies on the reluctant and struggling readers who served as cases in this study. As a multiple case study, this 
Strengthening the reader self-efficacies of reluctant and struggling readers through literature circles

study also necessitated cross-case analysis. Yin (2014) recommends treating each case as a separate study. Thus, the author engaged in the data analysis spiral for each of the seven cases.

To analyze the quantitative data, the author used a dependent (paired) samples t-test to determine if the cases' reader self-efficacies, as measured by the RSPS, changed following their participation in literature circles. A dependent (paired) samples t-test was used to analyze the data because the same cases were tested twice using the RSPS, as suggested by Kirk (2008). The author also utilized a dependent (paired) samples t-test to analyze the RSPS pre- and post-test scores of the other study participants who did not serve as cases (i.e. students with higher reader self-efficacies). Described below are the results and findings from both qualitative and quantitative data analyses.

\section{Results and Findings}

The self-reported reader self-efficacies of the reluctant and struggling readers who served as cases in this study improved between the RSPS pre-and post-tests. These results corroborate findings from qualitative data. Yet the influence of literature circle participation on the reader self-efficacies of the other study participants (i.e. students with higher reader self-efficacies) was not as pronounced.

\section{Seven cases: Reluctant and struggling readers}

As measured by the RSPS (Henk \& Melnick, 1995), the self-reported reader selfefficacies of the reluctant and struggling readers who served as cases in this study improved from pre-test to post-test. Table 2 summarizes the results from quantitative analysis. Results from the dependent (paired) samples t-test indicated a statistically significant difference between cases' RSPS pre-test scores $(M=2.99, S D=0.50)$ and their post-test scores $(M=3.69, S D=0.45) ; t(6)$ $=-3.76, \mathrm{p}=.009 ; d=1.41$. The effect size for this analysis $(d=1.41)$ was found to exceed 
Strengthening the reader self-efficacies of reluctant and struggling readers through literature circles

Cohen's $(1988)$ convention for a large effect $(d=0.80)$. These statistically significant results suggest the self-reported reader self-efficacies of reluctant and struggling readers increased from pre-test to post-test. In addition to the collective improvement in the reader self-efficacies of the cases, the reader self-efficacy of each case improved following his or her participation in literature circles. The mean RSPS (RSPS) pre- and post-test scores for each case as well as his or her pre- and post-test scores for each scale are found in Table 3. Overall, the reader selfefficacies of the seven reluctant and struggling readers who served as cases in this study improved, as demonstrated by gains in their RSPS scores from pre-test to post-test and as supported by qualitative data.

Grace. Prior to literature circles, Grace described herself as a reader by remarking, "I'm a good reader depending on what time of day it is," adding she reads best in the afternoon when she is neither sleepy nor grumpy (Grace, personal communication, October 2016). On her final role sheet, Grace wrote, "I also injoy [enjoy] doing it like this [reading the novel in a literature circle] because it gets stuff done" (Grace, documentation, January 2017). In an interview following the conclusion of the eight-week literature circle cycle, Grace expressed her enjoyment of reading by stating, "Yes...because I found interesting books that I like" (Grace, personal communication, February 2017). The author asked Grace what led to the improvement between her RSPS pre- and post-test scores. Grace explicitly attributed her improved scores to "the literature circle books... because I actually read it and I enjoyed it and I wrote about [it] too" (Grace, personal communication, February 2017). As in the first interview, Grace described herself as a "good reader" (Grace, personal communication, February 2017). This time, however, Grace offered a specific example_- "I can actually find words, and I know what the words mean" (Grace, personal communication, February 2017) — to support her assertion and did not attribute 
Strengthening the reader self-efficacies of reluctant and struggling readers through literature circles

her reading ability to a particular time of day. Reflecting on her literature circle experience,

Grace remarked, "People in my group [literature circle] helped me understand the words too"

(Grace, personal communication, February 2017). Furthermore, Grace stated, "It [literature

circles] changed me to read more and like the books I read" (Grace, personal communication,

February 2017). During the focus group, Grace stated literature circles "takes up time, but I liked it because you know, I didn't have to do work a lot” (Grace, focus group, February 2017). The author asked the cases to consider whether participating in a literature circle changed their perceptions of themselves as students. Grace responded, "Well, yeah, 'cause I like to read now" (Grace, focus group, February 2017).

Humberto. When asked if he enjoys reading during the initial interview, Humberto responded, "[Reading] sometimes takes time like away from fun things" (Humberto, personal communication, October 2016). Humberto admitted that reading was challenging for him. "Sometimes it's hard to think about the reading, and I sometimes don't know words that are being used. And it's really hard to understand what a question means" (Humberto, personal communication, October 2016). On his final role sheet, Humberto wrote, "I enjoy the book in groups [i.e. literature circles] because it's much easier to learn about the book" (Humberto, documentation, January 2017). Like Grace, Humberto credited differences between his RSPS pre- and post-tests scores to his participation in literature circles. In the post-literature circle interview, Humberto was asked what led to improvement between his initial RSPS scores and post-test scores to which he responded, "when we were doing literature circles" (Humberto, personal communication, February 2017). In the same interview, Humberto stated he liked reading "a little bit" but added that some books were too long for his taste (Humberto, personal communication, February 2017). Notably, Humberto stated “defining words” (Humberto, 
Strengthening the reader self-efficacies of reluctant and struggling readers through literature circles

personal communication, February 2017) was one of his strengths as a reader although prior to participating in literature circles he voiced that vocabulary was challenging for him. Humberto's attitude towards reading seemed to improve minutely after participating in literature circles because he stated he would still rather "do something else instead of reading" (Humberto, personal communication, February 2017). During the focus group, the author asked the cases if literature circles differed from the usual reading instruction they received. Humberto responded, "I mean, like, yeah. It's [literature circles] less boring, and we have more conversations" (Humberto, focus group, February 2017).

Lucita. Prior to participating in literature circles, the author asked Lucita if she likes to read to which she responded, "No. Not a lot" (Lucita, personal communication, October 2016). In reflecting on Lucita as a reader prior to literature circles, Mrs. Ian commented, "[Lucita] masked it [i.e. struggling with reading] very well, very well. She would smile and say she has it when she didn't' (Mrs. Ian, personal communication, February 2017). In the post-literature circle interview, the author again asked Lucita if she enjoys reading. Lucita responded, "Well, since last time [i.e. October 2016], I kind of am starting to get used to it and liking it" (Lucita, personal communication, February 2017). Lucita attributed her newfound affinity for reading to being able to visualize the text and concentrate on words, adding, "I'm starting to learn bigger words" (Lucita, personal communication, February 2017). Lucita stated that "It's [literature circles] helping me understand the reading" (Lucita, personal communication, February 2017). Lucita ended our post-literature circle interview by commenting, "I improved...I'm getting smartergrowing more" (Lucita, personal communication, February 2017). Mrs. Ian likewise noted Lucita's improvement as a reader by stating, "It [literature circles] gave her an avenue to begin practicing skills she's learning, and I think for her, it helped cement some of that understanding. 
Strengthening the reader self-efficacies of reluctant and struggling readers through literature circles

I think it's been helping her improve. I think it's been helping her a lot” (Mrs. Ian, personal communication, February 2017).

Naomi. The author asked Naomi if she enjoyed reading during our initial interview. Naomi responded, "Not really," and when pressed by the author retorted, "“Cause I don't know; it's just I don't like to read" (Naomi, personal communication, October 2016). Furthermore, Naomi stated she read only when "Mrs. Ian tells me to" (Naomi, personal communication, October 2016). Upon reflecting on Naomi as a reader prior to literature circles, Mrs. Ian characterized her as a reluctant reader by stating, "Naomi is a strong reader, just does not always want to read. She's...highly capable; she's just very reluctant” (Mrs. Ian, personal communication, February 2017). On her final role sheet Naomi wrote, "If I had another chance to do another lit meeting I would only [emphasis hers] if the book had pictures" (Naomi, documentation, January 2017). During the interview following the eight-week literature circle cycle, Naomi described her literature circle experience in the following manner, "It wasn't as bad as I thought it was going to be. I thought it was going to be like very boring and stuff, but it wasn't that boring" (Naomi, personal communication, February 2017). Naomi described herself as an "intelligent reader," adding, “"cause I can say words that most kids can’t, and I can like read better-like if the words is really long, I could probably figure it out" (Naomi, personal communication, February 2017). Naomi attributed differences between her RSPS pre- and posttest scores to "reading like longer books instead of reading like shorter books" (Naomi, personal communication, February 2017).

Tomás. Tomás stated he enjoyed reading during our initial interview, adding, "It's better for you...at school” (Tomás, personal communication, October 2016). Tomás described himself as an "okay reader," (Tomás, personal communication, October 2016) admitting that he 
Strengthening the reader self-efficacies of reluctant and struggling readers through literature circles

struggled with vocabulary and needed help at times. Reflecting upon Tomás as a reader prior to participating in literature circles, Mrs. Ian characterized Tomás as both a reluctant and struggling reader. Mrs. Ian stated, 'I think his [Tomás'] behaviors were getting in the way because he was basically doing anything he could to avoid participating in anything dealing with reading" (Mrs. Ian, personal communication, February 2017). During the post-literature circle interview, Tomás stated, "I think reading's fun and interesting” (Tomás, personal communication, February 2017). After participating in literature circles, Tomás described himself as a "good" reader but added that he still "struggle[s] sometimes with words" (Tomás, personal communication, February 2017).The author asked Tomás about the improvement between his RSPS pre-test and post-test scores. Tomás responded, "Because last time I took it [i.e. RSPS pre-test], I was struggling with words more than when I took it again [i.e. RSPS post-test]. I was kind of not getting stuck" (Tomás, personal communication, February2017). Later in the same interview, Tomás was asked if literature circles changed him as a reader to which he answered, "Some words I didn't understand, but I took the book home and I read it overnight and I brought it back to school and so for our literature circle, I know what the words mean" (Tomás, personal communication, February2017). Mrs. Ian—who was Tomás' teacher the previous two years—noted that Tomás’ demeanor towards reading changed after participating in literature circles. Mrs. Ian commented, "He [Tomás] wants to read, which is very different...from the fourth-grader I started off with or even the fifth-grader I had" (Mrs. Ian, personal communication, February 2017). Mrs. Ian added that while in Grades 4 and 5, Tomás "would just kind of fall out in the middle of the floor and drag his feet and do everything he could to avoid it [reading]" (Mrs. Ian, personal communication, February 2017). Furthermore, Mrs. Ian stated, "During literature circles, I saw several changes with him [Tomás]. He's already asked to borrow two or three books out of my 
Strengthening the reader self-efficacies of reluctant and struggling readers through literature circles

teacher library. Now he asks me, 'Can I go outside and read?' Like he wants to read, which is very different" (Mrs. Ian, personal communication, February 2017).

Will. In our initial interview, Will responded to a question about whether he enjoys reading by stating, "Sometimes I don't want to read. Sometimes I kind of don't” (Will, personal communication, October 2016). Mrs. Ian said, "I think when he [Will] is presented with more challenging reading then he draws back. He is reading on grade level according to every reading inventory I have, but I figured out it's not 'I can't,' it's 'I don't want to'” (Mrs. Ian, personal communication, February 2017). During the third week of literature circles, the author overheard Will telling Mrs. Ian, "I hate reading” (Will, observation, December2016). Similarly, in week four, the student functioning in the role of Discussion Director posed a question regarding the group members' least favorite parts of the book. Will retorted, "Reading. Because I hate reading" (Will, observation, December2016). Throughout the fourth literature circle meeting, Will continually answered, "I hate reading” (Will, observation, December2016), regardless of the question posed. However, Will's attitude towards both literature circle participation and reading seemingly changed halfway through literature circles. The author did not overhear Will express his hatred of reading beginning in week five nor in the remaining weeks. On his final role sheet, Will reflected on his literature circle experience by characterizing literature circles as “sometimes boring and sometimes good and funny" (Will, documentation, January 2017). During the second (i.e. post-literature circle) interview, Will offered this response to a question regarding his enjoyment of reading, "Yes because I like to read comics, and no, because sometimes I don't like to read" (Will, personal communication, February 2017). During the focus group, the author asked the cases if participating in a literature circle led them to want to read more, less, or the same as before. Strikingly, Will answered, "I like reading” (Will, personal 
Strengthening the reader self-efficacies of reluctant and struggling readers through literature circles

communication, February 2017). Mrs. Ian noted some changes in Will's demeanor towards

reading following his participation in literature circles. Mrs. Ian commented,

I think it [literature circles] made a little bit of a difference because even though he [Will] would kind of just say 'I still don't want to.' He still does it. And that I found interesting because before I wouldn't have even been able to get him to even want to and then do it. He would say, 'I don't want to' and then not. But now I saw where he was actually putting forth the effort to do it and so that made a huge difference for him (Mrs. Ian, personal communication, February 2017).

Ximena. Prior to literature circles, Ximena expressed to the author her enjoyment of reading. Ximena stated, "I just like to find out what kind of stories are there and...I just like to read" (Ximena, personal communication, October 2016). Ximena admitted reading could be challenging for her by stating, "Sometimes I mess up the words" (Ximena, personal communication, October 2016). Mrs. Ian offered this characterization of Ximena, "I saw her as more of a struggling reader” (Mrs. Ian, personal communication, February 2017). On her final role sheet, Ximena wrote, "It [literature circles] was good. I liked it" (Ximena, documentation, January 2017). During our second interview, Ximena expressed that she liked literature circles because "I get to read and I get to write what is funny and what's the problem" (Ximena, personal communication, February 2017). Like Grace and Humberto, Ximena attributed improvement in her reader self-efficacy to participating in literature circles. When asked about differences between her RSPS pre- and post-test scores, Ximena offered the following explanation for her improvement: "Because I wasn't a very good reader until I read and read every single day for our literature circle, and it made me a better reader" (Ximena, personal communication, February2017). Furthermore, Ximena stated participating in literature circles helped her to "think of me as smart - a good reader" (Ximena, personal communication, February 2017). Mrs. Ian noted changes in Ximena following the literature circle cycle. Mrs. Ian stated, "Literature circles has helped kind of add to that confidence level and to use what she's 
Strengthening the reader self-efficacies of reluctant and struggling readers through literature circles

[Ximena's] read and use what she's learning on a deeper level" (Mrs. Ian, personal communication, February 2017).

The reader self-efficacies of each reluctant reader and struggling reader who served as a case in this study improved as measured by the RSPS (Henk \& Melnick, 1995) and as supported by qualitative data. Thus, the results and findings of this study suggest literature circles can be influential in strengthening the reader self-efficacies of reluctant and struggling readers. Yet participating in a literature circle did not produce similar results in the other study participants.

\section{Other study participants}

Upon examining the quantitative data for Mrs. Ian's class, one surprising finding was that literature circle participation did not yield positive change in the self-reported reader selfefficacies of the other study participants. Table 4 synthesizes the results of the dependent (paired) samples t-test for other study participants, which decreased slightly (by 0.25 points) between pre- and post-test. These results contrasted those of the seven cases. Within this embedded multiple case study, qualitative data was collected only from the reluctant and struggling readers who served as cases because they were the primary focus of this study and met the sampling criterion. Since the other study participants (i.e. students with initially higher reader self-efficacies) were not the intended focus of this study, the author did not collect qualitative data from these students.

\section{Discussion}

The results and findings of this study suggested participating in literature circles could potentially improve the reader self-efficacies of reluctant and struggling readers. The reader selfefficacies of three reluctant readers (i.e. Grace, Humberto, and Naomi), two struggling readers 
Strengthening the reader self-efficacies of reluctant and struggling readers through literature circles

(i.e. Lucita and Ximena), and two students identified as both reluctant and struggling readers (i.e. Tomás and Will) improved as demonstrated by an increase in their RSPS scores from pre- to post-test. Moreover, findings from qualitative data analysis suggest participating in literature circles positively influenced each of the seven cases. Four of the seven cases (i.e. Grace, Humberto, Tomás, and Ximena) explicitly stated that participating in literature circles led to improvements between their RSPS pre- and post-test scores. Mrs. Ian vocalized improvement in four of the seven cases (i.e. Lucita, Tomás, Will and Ximena) regarding their demeanors towards reading and/or reading skills. Five of the seven cases identified at least one strength, in terms of their reading ability, following their participation in literature circles. More specifically, Grace, Humberto, Lucita, and Naomi explicitly mentioned their abilities to problem-solve unknown words as a strength whereas Ximena expressed an overall improvement in herself as a reader.

Educators must be intentional in seeking to strengthen the reader self-efficacies of reluctant and struggling readers. The author designed this embedded multiple case study to explore the potential influence of participating in literature circles on the reader self-efficacies of reluctant and struggling readers in Grades 4-6. Prior to conducting this study, the author predicted the reader self-efficacies of the seven reluctant and struggling readers who served as cases in this study would be positively influenced, or strengthened, following their participation in literature circles. Social cognitive theory informed both this prediction and framed this study. Vicarious experience, or observing others' success in a given task, is one source that informs self-efficacy. Within the context of this study, the author postulated that cases' self-efficacies could potentially be strengthened as they observed their peers demonstrating success within literature circles. Participation in literature circles could potentially provide cases the opportunity to garner mastery experiences with reading as well as solicit feedback from their literature circle 
Strengthening the reader self-efficacies of reluctant and struggling readers through literature circles

members, both of which could likewise inform self-efficacy. This study is significant because, as previously mentioned, the reader self-efficacies of Grades 4-6 students often do not correlate with their reading abilities. Therefore, there is a need to strengthen the reader self-efficacies of reluctant and struggling readers to improve their affinities for reading and arguably, their reading achievement.

While some may suggest the RSPS scores of cases increased from pre- to post-test due to their natural growth over the course of the school year, the author argues against this notion. First, as mentioned in the review of related literature, there is a lack of calibration between the reading abilities and the reading self-efficacies of Grades 4-6 students (Corkett et al., 2011; Linnenbrink \& Pintrich, 2003; Pajares, 2003; Smith et al., 2012). Thus, although the reading ability of cases may have improved over the duration of the school year and course of this study, prior research suggests improved reading ability does not necessarily translate into improved reader self-efficacy. Furthermore, outside of literature circles, students read only short passages focused on improving their reading subskills in preparation for the annual state standardized exam. An interview with Mrs. Ian attests to this notion as she stated, "So much of what we read in class and even on our STAAR [i.e. State of Texas Assessments of Academic Readiness] test is very quick, short reads" (Mrs. Ian, personal communication, February 2017). Reading short passages designed to improve reading subskills and/or for test preparation is unlikely to contribute to long-term reading growth. As Cabral-Marquez (2015) explains, "It is only through sustained, active engagement with text that students will encounter natural, genuine opportunities to integrate all the skills and strategies that comprise the reading process and lead to growth in reading" (p. 464). Thus, the author contends the authentic literature read for literature circles was more likely influential on the reader self-efficacies of cases than the more frequently utilized 
Strengthening the reader self-efficacies of reluctant and struggling readers through literature circles

shorter, subskills-focused texts. Comments from the cases and their classroom teacher suggest the same. Finally, higher self-efficacy is unlikely to be sustained if students are unsuccessful in a given task (Schunk \& Zimmerman, 2007). Therefore, the cases' elevated reader self-efficacies were more likely due to their successful participation in literature circles, which was the only changed variable in the type of reading instruction they received from Mrs. Ian over the course of the school year. Furthermore, participating in literature circles did not have the same influence on the reader self-efficacies of the other study participants, whose reader self-efficacies were initially higher. The incongruence in RSPS post-test results for cases and other study participants further suggests participating in literature circles can potentially strengthen the reader selfefficacies of reluctant and struggling readers. As previously mentioned both cases and other study participants intermingled in literature circles as well as read and discussed the same novel. Additionally, Mrs. Ian changed the membership of each literature circle from week-to-week. Since both cases (i.e. reluctant and struggling readers with initially lower reader self-efficacies) and other study participants (i.e. students with initially higher reader self-efficacies) were subjected to the same aforementioned conditions yet produced different results on their RSPS post-tests, the plausibility that literature circle participation increased the reader self-efficacies of cases is merited.

\section{Connection to prior research}

The results and findings of this study contribute to existing research on self-efficacy as well as literature circles/text-based discussions. Results and findings of this study corroborate those from previous research that suggested literature circle participation could increase the confidence of young readers (Blum, Lipsett, \& Yocom, 2002; Lewis, 1997). For example, Mrs. Ian noted the confidence of Ximena—whom she previously identified as a struggling reader — as 
Strengthening the reader self-efficacies of reluctant and struggling readers through literature circles

a reader improved after her participation in literature circles. Likewise, results and findings from this study support those found by previous studies which suggested literature circles increase students' motivation to read (Stein \& Beed, 2004) and enjoyment of reading (Cameron et al., 2012). Grace, Lucita, and Ximena vocalized to the researcher an improvement in their enjoyment of reading whereas Tomás and Will demonstrated to both Mrs. Ian and the researcher an improvement in their enjoyment of reading.

Literature circles provide a context for students to model their thought processes for their other group members (Smith, 2012). As previously mentioned, a student's observation of others can influence his or her self-efficacy (Schunk \& Zimmerman, 2007). Linking the two together, previous research conducted by Hall (2012) found text-based discussion groups could benefit struggling readers as they have the opportunity to observe their peers utilizing various reading strategies. This study expands upon Hall's (2012) findings by suggesting literature circles, which revolve around text-based discussion, can potentially improve the reader self-efficacies of reluctant and struggling readers.

\section{Limitations}

There are primarily two limitations to this study. The first is that it is unknown whether reluctant and/or struggling readers were present in the pool of other study participants. However, the author took steps to mitigate this issue by conferring with Mrs. Ian to identify potential cases for further study. Moreover, Mrs. Ian did not identify any of the other study participants—who demonstrated initially higher reader self-efficacies_ - as either reluctant or struggling readers. Prior research by Valdez (2013) supports the validity of teachers' judgements of their students' literacy skills. Consequently, the author trusted Mrs. Ian's professional judgment, especially since she taught some of the cases during the previous school year(s). 
Strengthening the reader self-efficacies of reluctant and struggling readers through literature circles

As an embedded multiple case study, this study was primarily qualitative in nature;

therefore, the author cannot speak to the generalizability of the results and findings. Moreover, as a case study, the cases and other study participants were bound to the unique context of Mrs.

Ian's Grades 4-6 classroom. Therefore, the results and findings that emerged from this study may not translate to other contexts. The quantitative data collected for this study served two purposes: (1) to help identify potential cases for further study and (2) to supplement the qualitative data. Thus, the sample size (i.e. $n=7$ for cases; $n=10$ for other study participants) is too small to warrant deeper analysis. Furthermore, the author employed criterion-based purposeful sampling to identify the seven cases. All students took part in literature circles; therefore, there was neither a treatment nor a control group.

\section{Future Research}

Future research into literature circles, or text-based discussion groups, and reader selfefficacy is needed, particularly regarding the reader self-efficacies of students who tend to be more successful in more traditional literacy instructional contexts than reluctant or struggling readers. The author suggests quasi-experimental studies on the potential influence of literature circles, or text-based discussion groups, on reader self-efficacy be conducted. Conducting such quasi-experimental research in separate classrooms would allow for the creation of both a control group (i.e. students who do not participate in literature circles) and a treatment group (i.e. students who do participate in literature circles). Nevertheless, this study suggests literature circles may influence the reader self-efficacies of reluctant and struggling readers.

\section{Conclusion}

The results and findings of this study suggest participating in a literature circle can potentially strengthen the reader self-efficacies of reluctant and struggling readers. This study is 
Strengthening the reader self-efficacies of reluctant and struggling readers through literature circles

significant because similar results were not found for the other study participants with initially higher reader self-efficacies. Thus, this study provides support for the utilization of literature circles - a balanced literacy instructional strategy that is engaging, student-centered, and holistic — to potentially boost the reader self-efficacies of reluctant and struggling readers in Grades 4-6. As previously mentioned, Grades 4-6 students often fail to calibrate their selfefficacies and reading abilities (Corkett et al., 2011; Linnenbrink \& Pintrich, 2003; Pajares, 2003; Smith et al., 2012). The author of this study argues that literature circles — an engaging, more student-centered, and holistic approach to reading instruction-merits inclusion in Grades 4-6 classrooms for its potential to strengthen the reader self-efficacies of reluctant and struggling readers. 
Strengthening the reader self-efficacies of reluctant and struggling readers through literature circles

\section{Tables}

Table 1

Case demographics

\begin{tabular}{ccccc}
\hline Case & Race/ethnicity & Grade & Reluctant reader & Struggling reader \\
\hline Grace & African-American & $5^{\text {th }}$ & X & \\
Humberto & Latinx & $5^{\text {th }}$ & X & \\
Lucita & Latinx & $4^{\text {th }}$ & & X \\
Naomi & African-American & $5^{\text {th }}$ & X & X \\
Tomás & Latinx & $6^{\text {th }}$ & X & X \\
Will & Caucasian & $6^{\text {th }}$ & X & X \\
Ximena & Latinx & $4^{\text {th }}$ & & \\
\hline
\end{tabular}

Table 2

Results of dependent samples t-test for cases' RSPS scores

\begin{tabular}{|c|c|c|c|c|c|c|c|c|}
\hline \multirow[t]{2}{*}{ Outcome } & \multicolumn{2}{|c|}{ Pre-test } & \multicolumn{2}{|c|}{ Post-test } & & \multirow[t]{2}{*}{$\begin{array}{c}95 \% \text { CI for } \\
\text { Mean } \\
\text { Difference }\end{array}$} & \multirow[b]{2}{*}{$\mathrm{D}$} & \multirow[b]{2}{*}{$\mathrm{t}$} \\
\hline & M & SD & M & SD & $\mathrm{n}$ & & & \\
\hline & 2.99 & 0.50 & 3.69 & 0.45 & 7 & $-1.14,0.24$ & 1.41 & -3.76 \\
\hline
\end{tabular}

$* \mathrm{p}<.05$. 
Table 3

Cases' RSPS (RSPS) pre- and post-test scores

\begin{tabular}{|c|c|c|c|c|c|c|c|c|c|c|c|c|}
\hline Case & $\begin{array}{l}\text { RSPS } \\
\text { Pre- } \\
\text { test } \\
(\mathrm{M})\end{array}$ & $\begin{array}{l}\text { RSP } \\
\text { S } \\
\text { Post } \\
\text {-test } \\
\text { (M) }\end{array}$ & $\begin{array}{l}\text { Progre } \\
\text { ss } \\
\text { Scale } \\
\text { pre- } \\
\text { test }\end{array}$ & $\begin{array}{l}\text { Progre } \\
\text { ss } \\
\text { Scale } \\
\text { post- } \\
\text { test }\end{array}$ & $\begin{array}{c}\text { Observatio } \\
\text { nal } \\
\text { Compariso } \\
\text { n Scale } \\
\text { pre-test }\end{array}$ & $\begin{array}{c}\text { Observatio } \\
\text { nal } \\
\text { Compariso } \\
\text { n Scale } \\
\text { post-test }\end{array}$ & $\begin{array}{c}\text { Social } \\
\text { Feedba } \\
\text { ck } \\
\text { Scale } \\
\text { pre-test }\end{array}$ & $\begin{array}{c}\text { Social } \\
\text { Feedba } \\
\text { ck } \\
\text { Scale } \\
\text { post- } \\
\text { test }\end{array}$ & $\begin{array}{l}\text { Physiologi } \\
\text { cal States } \\
\text { Scale pre- } \\
\text { test }\end{array}$ & $\begin{array}{l}\text { Physiologi } \\
\text { cal States } \\
\text { Scale } \\
\text { post-test }\end{array}$ & $\begin{array}{c}\text { "I } \\
\text { think } \\
\text { I am } \\
\text { a } \\
\text { good } \\
\text { reade } \\
\text { r" } \\
\text { pre- } \\
\text { test }\end{array}$ & $\begin{array}{c}\text { "I } \\
\text { think } \\
\text { I am } \\
\text { a } \\
\text { good } \\
\text { reade } \\
\text { r" } \\
\text { post- } \\
\text { test }\end{array}$ \\
\hline Grace & 3.69 & 4.06 & 44 & 45 & 19 & 19 & 26 & 32 & 29 & 33 & 4 & 4 \\
\hline Humberto & 3.03 & 3.21 & 24 & 27 & 15 & 13 & 27 & 35 & 30 & 28 & 4 & 3 \\
\hline Lucita & 2.43 & 3.72 & 23 & 40 & 11 & 22 & 22 & 30 & 19 & 28 & 3 & 3 \\
\hline Naomi & 3.33 & 4.03 & 34 & 43 & 21 & 28 & 29 & 32 & 22 & 26 & 4 & 4 \\
\hline Tomás & 2.53 & 3.96 & 22 & 40 & 12 & 21 & 23 & 32 & 25 & 34 & 2 & 4 \\
\hline Will & 2.54 & 2.90 & 26 & 37 & 18 & 20 & 22 & 24 & 15 & 12 & 3 & 3 \\
\hline Ximena & 3.43 & 3.93 & 32 & 34 & 12 & 22 & 27 & 38 & 33 & 32 & 3 & 4 \\
\hline
\end{tabular}




\section{Table 4}

Results of dependent samples t-test for other study participants' RSPS scores

\begin{tabular}{|c|c|c|c|c|c|c|c|c|}
\hline \multirow[t]{2}{*}{ Outcome } & \multicolumn{2}{|c|}{ Pre-test } & \multicolumn{2}{|c|}{ Post-test } & & \multirow[t]{2}{*}{$\begin{array}{l}95 \% \text { CI for } \\
\text { Mean } \\
\text { Difference }\end{array}$} & \multirow[b]{2}{*}{ d } & \multirow[b]{2}{*}{$\mathrm{t}$} \\
\hline & $\mathrm{M}$ & SD & $\mathrm{M}$ & SD & $\mathrm{n}$ & & & \\
\hline & 3.99 & 0.39 & 3.74 & 0.71 & 10 & $-0.09,0.58$ & 0.52 & 1.65 \\
\hline
\end{tabular}

$* \mathrm{p}<.05$. 
Strengthening the reader self-efficacies of reluctant and struggling readers through literature circles

\section{References}

Allington, R. L. (1983). The reading instruction provided readers of differing reading abilities. The Elementary School Journal, 83(5), 548-559.

Angrosino, M.V. (2007). Doing ethnographic and observational research. Thousand Oaks, CA: SAGE Publications, Inc.

Avci, S., \& Yuksel, A. (2011). Cognitive and affective contributions of the literature circles method on the acquisition of reading habits and comprehension skills in primary level students. Educational Sciences: Theory \& Practice, 11(3), 1295-1300.

Bandura, A. (1997). Self-efficacy: The exercise of control. New York, NY: Freeman.

Bandura, A. (2001). Social cognitive theory: An agentic perspective. Annual Review of Psychology, 52, 1-26.

Bandura, A. \& Schunk, D.H. (1981). Cultivating competence, self-efficacy, and intrinsic interest through proximal self-motivation. Journal of Personality and Social Psychology, 41, 586-598.

Beers, K. (1996). Choosing not to read: Understanding why some middle schoolers just say no. In K. Beers \& B.G. Samuels (Eds.), Into focus: Understanding and creating middle school readers (pp. 1-27). Norwood, MA: Christopher-Gordon Publishers.

Blum, H.T., Lipsett, L.R., \& Yocom, D.J. (2002). Literature circles: A tool for self-determination in one middle school inclusive classroom. Remedial and Special Education, 23(2), 99108. doi: $10.1177 / 074193250202300206$

Brinda, W. A. (2011). "Ladder to literacy" engages reluctant readers: Students help create a new approach to reading and enjoying literature assigned in school. Middle School Journal, $43(2), 8-17$.

Bryman, A. (2006). Integrating quantitative and qualitative research: How is it done? Qualitative Research, 6(1), 97-113.

Cabral-Marquez, C. (2015). Motivating readers: Helping set and attain personal reading goals. The Reading Teacher, 68(6), 464-472.

Cameron, S., Murray, M., Hull, K., \& Cameron, J. (2012). Engaging fluent readers using literature circles. Literacy Learning: The Middle Years, 20(1), 1-8.

Carrison, C. \& Ernst-Salvit, G. (2005). From silence to a whisper to active participation: Using literature circles with ELL students. Reading Horizons, 46(2), 93-113.

Chambers, A. (1969). The reluctant reader. Oxford, U.K.: Pergamon Press.

Cho, E. Roberts, G.J., Capin, P., Roberts, G., Miciak, J., \& Vaughn, S. (2015). Cognitive attributes, attention, and self-efficacy of adequate and inadequate responders in a fourth grade reading intervention. Learning Disabilities Research \& Practice, 30(4), 159-170.

Clarke, L.W., \& Holwadel, J. (2007). "Help! What is wrong with these literature circles and how can we fix them?" The Reading Teacher, 61(1), 20-29.

Cohen, J. (1988). Statistical power analysis for the behavioral sciences $\left(2^{\text {nd }}\right.$ ed.) Hillsdale, NJ: Lawrence Erlbaum.

Cooper, J.D., Robinson, M.D., Slansky, J.A., \& Kiger, N.D. (2015). Literacy: Helping students construct meaning ( $9^{\text {th }}$ ed.) Stamford, CT: Cengage Learning.

Corkett, J., Hatt, B., \& Benevides, T. (2011). Student and teacher self-efficacy and the connection to reading and writing. Canadian Journal of Education, 34(1), 65-98.

Creswell, J.W. (2013). Qualitative inquiry and research design: Choosing among five approaches ( $2^{\text {nd }}$ ed.). Los Angeles, CA: SAGE Publications, Inc. 
Strengthening the reader self-efficacies of reluctant and struggling readers through literature circles

Daniels, H. (2002). Literature circles: Voice and choice in book clubs \& reading groups. Portland, ME: Stenhouse Publishers.

Day, J.P., Spiegel, D.L., McLellan, J. \& Brown, V. B. (2002). Moving forward with literature circles: How to plan, manage, and evaluate literature circles that deepen understanding and foster a love of reading. New York, NY: Scholastic Professional Books.

Ferrara, S.L. (2005). 20 ways to promote reader self-efficacy. Intervention in School and Clinic, 41(1), 36-38.

Guthrie, J.T., Hoa, A.L.W., Wigfield, A., Tonks, S.M., Humenick, N.M., \& Littles, E. (2007). Reading motivation and reading comprehension growth in later elementary years. Contemporary Educational Psychology, 32, 282-313.

Hall, L.A. (2012). Moving out of silence: Helping struggling readers find their voices in textbased discussions. Reading \& Writing Quarterly: Overcoming Learning Difficulties, 28(4), 307-332.

Henk, W.A. \& Melnick, S.A. (1992). The initial development of a scale to measure "perception of self as reader.” In C.K. Kinzer \& D.J. Leu (Eds.) Literacy research, theory, and practice: Views from many perspectives (pp. 111-117). Chicago, IL: National Reading Conference.

Henk, W.A. \& Melnick, S.A. (1995). The RSPS (RSPS): A new tool for measuring how children feel about themselves as readers. The Reading Teacher, 48(6), 470-482.

Hoyte, C.A. (2006). Authors hook reluctant readers. Canadian Children's Book News, 29(4), 10.

Kent, S.C., Wanzek, J., \& Al Otaiba, S. (2017). Reading \& Writing Quarterly: Overcoming Learning Difficulties, 33(5), 395-411. DOI: 10.1080/10573569.2016.1216342

Kim, J.S., Hemphill, L., Troyer, M., Thomson, J.M., Jones, S.M., LaRusso, M.D., \& Donovan, S. (2016). Engaging struggling adolescent readers to improve reading skills. Reading Research Quarterly, 52(3), 357-382. doi: 10.1002/rrq.171.

Kirk, R. (2008). Statistics: An introduction ( $5^{\text {th }}$ ed.). Belmont, CA: Thomson Higher Education.

Lewis, C. (1997). The social drama of literature discussions in a fifth/sixth grade classroom. Research in the Teaching of English, 31, 163-204.

Lincoln, Y.S. \& Guba, E.G. (1985). Naturalistic inquiry. Beverly Hills, CA: SAGE Publications, Inc.

Linnenbrink, E.A. \& Pintrich, P.R. (2003). The role of self-efficacy beliefs in student engagement and learning in the classroom. Reading \& Writing Quarterly: Overcoming Learning Difficulties, 19(2), 119-137.

Lord, C. (2008). Rules. New York, NY: Scholastic Paperbacks.

McCabe, P. (2003). Enhancing self-efficacy for high-stakes reading tests. The Reading Teacher, 57(1), 12-20.

McCabe, P. \& Margolis, H. (2001). Enhancing the self-efficacy of struggling readers. The Clearing House, 75(1), 45-49.

Pajares, F. (2003). Self-efficacy beliefs, motivation, and achievement in writing: A review of the literature. Reading \& Writing Quarterly: Overcoming Learning Difficulties, 19(2), 139158.

Palinkas, L.A., Horwitz, S.M., Green, C.A., Wisdom, J.P., Duan, N., \& Hoagwood, K. (2013). Purposeful sampling for qualitative data collection and analysis in mixed method implementation research. Administration and Policy in Mental Health and Mental Health Services Research, 42(5), 533-544. 
Strengthening the reader self-efficacies of reluctant and struggling readers through literature circles

Pearson, C. (2010). Acting up or acting out? Unlocking children's talk in literature circles. Literacy, 44(1), 3-11.

Scammacca, N.K., Roberts, G., Vaughn, S., \& Stuebing, K.K. (2015). A meta-analysis of interventions for struggling readers in grades 4-12: 1980-2011. Journal of Learning Disabilities, 48(4), 369-390.Schunk, D.H. (1987). Peer models and children's behavioral change. Review of Educational Research, 57, 149-174.

Schunk, D.H. \& Zimmerman, B.J. (2007). Influencing children's self-efficacy and selfregulation of reading and writing through modeling. Reading \& Writing Quarterly: Overcoming Learning Difficulties, 23(1), 7-25.

Shell, D.F., Colvin, C., \& Bruning, R.H. (1995). Self-efficacy, attribution, and outcome expectancy mechanisms in reading and writing achievement: Grade-level and achievement level differences. Journal of Educational Psychology, 87, 386-398.

Smith, V. (2012). Making reading mean: Revised edition. UKLA Publications: Royston, UK.

Smith, J.K., Smith, L.F., Gilmore, A., Jameson, M. (2012). Students's self-perception of reading ability, enjoyment of reading and reading achievement. Learning and Individual Differences, 22, 202-206.

Solheim, O.J. (2011). The impact of reading self-efficacy and task value on reading comprehension scores in different item formats. Reading Psychology, 32(1), 1-27.

Stein, D., \& Beed, P.L. (2004). Bridging the gap between fiction and nonfiction in the literature circle setting. The Reading Teacher, 57(6), 510-518.

Südkamp, A., Kaiser, J. \& Möller, J. (2012). Accuracy of teachers' judgments of students' academic achievement: A meta-analysis. Journal of Educational Psychology, 104(3), 743-762.

Thames, D.G., Reeves, C., Kazelskis, R., York, K., Boling, C., Newell, K. \& Wang, Y. (2008). Reading comprehension: Effects of individualized, integrated language arts as a reading approach with struggling readers. Reading Psychology, 29(1), 86-115. DOI: $10.1080 / 02702710701853625$.

Unrau, N. \& Schlackman, J. (2006). Motivation and its relationship with reading engagement: Clarifying comingled conceptions. Reading Psychology, 35(3), 260-284.

Valdez, A. (2013). Teacher judgment of reading achievement: Cross-sectional and longitudinal perspective. Journal of Education and Learning, 2(4), 186-200.

Wanzek, J., Wexler, J., Vaughn, S., \& Ciullo, S. (2010). Reading interventions for struggling readers in the upper elementary grades: A synthesis of 20 years of research. Reading and Writing, 23(8), 889-912. DOI: 10.1007/s11145-009-9179-5.

Whittaker, C.R. (2012). Integrating literature circles into a cotaught inclusive classroom. Intervention in School and Clinic, 47(4), 214-223. DOI: 10.1177/1053451211424601

Zimmerman, B.J. (2000). Self-efficacy: An essential motive to learn. Contemporary Educational Psychology, 25, 82-91. 